\title{
The Role of Choroid Plexus In IVIG-induced Beta-Amyloid Clearance
}

\author{
Huiying Gu ${ }^{\# 1}$, Zhaohui Zhong ${ }^{\# 1,2}$, Wendy Jiang ${ }^{3}$, Eileen Du ${ }^{1}$, Richard Dodel ${ }^{4}$, Martin R. \\ Farlow ${ }^{1}$, Wei Zheng ${ }^{3}$, and Yansheng Du ${ }^{1,3}$ \\ ${ }^{1}$ Department of Neurology, Indiana University School of Medicine, Indianapolis, IN, 46202 \\ 2Department of General Surgery, Peking University People's Hospital, Beijing 100044, China \\ ${ }^{3}$ School of Health Sciences, Purdue University, West Lafayette, IN, 47907 \\ ${ }^{4}$ Department of Neurology, Philipps University Marburg, Marburg, Germary. \\ \# These authors contributed equally to this work.
}

\section{Abstract}

We have shown that intravenous immunoglobulin (IVIG) contains anti-A $\beta$ autoantibodies and IVIG could induce beta amyloid (A $\beta$ ) efflux from cerebrospinal fluid (CSF) to blood in both Multiple Sclerosis (MS) and Alzheimer disease (AD) patients. However, the molecular mechanism underlying IVIG-induced $A \beta$ efflux remains unclear. In this study, we used amyloid precursor protein (A $\beta P P$ ) transgenic mice to investigate if the IVIG could induce efflux of A $\beta$ from the brain and whether low-density lipoprotein receptor-related protein-1 (LRP1), a hypothetic $\mathrm{A} \beta$ transporter in blood-cerebrospinal fluid barrier (BCB); could mediate this clearance process. We currently provide strong evidence to demonstrate that IVIG could reduce brain $A \beta$ levels by pulling $A \beta$ into the blood system in $A \beta P P$ transgenic mice. In the mechanistic study, IVIG could induce $A \beta$ efflux through the in-vitro $B C B$ membrane formed by cultured $B C B$ epithelial cells. Both RAP (receptor-associated protein; a functional inhibitor of LRP1), and LRP1 siRNA were able to significantly inhibit the $A \beta$ efflux. Should $A \beta$ prove to be the underlying cause of $\mathrm{AD}$, our results strongly suggest that IVIG could be beneficial in the therapy for Alzheimer's disease (AD) by inducing efflux of $A \beta$ from the brain through the LRP1 in the BCB.

\section{Keywords}

Choroid Plexus; IVIG; LRP1; A $\beta$ clearance

(C) 2014 IBRO. Published by Elsevier Ltd. All rights reserved.

Correspondence to: Yansheng Du, Ph.D. Department of Neurology School of Medicine, Indiana University Indianapolis, IN 46202 Tel: 317-278-0220 Fax: 317-274-3587 ydu@iupui.edu.

Publisher's Disclaimer: This is a PDF file of an unedited manuscript that has been accepted for publication. As a service to our customers we are providing this early version of the manuscript. The manuscript will undergo copyediting, typesetting, and review of the resulting proof before it is published in its final citable form. Please note that during the production process errors may be discovered which could affect the content, and all legal disclaimers that apply to the journal pertain. 


\section{Introduction}

Alzheimer's disease (AD) is the most common type of dementia in the elderly. Beta-amyloid (A $\beta$, a 39-42 amino acid proteolytic product of the amyloid precursor protein) accumulation in the brains extracellular space is believed to be one of several contributing factor to AD pathology (Ogomori et al., 1989). Increased levels of A $\beta$ in the brains of AD patients may result from either the overproduction of $A \beta$ or an inadequate metabolism/clearance within the brain. It may be a primary event that leads to amyloid plaque deposition and subsequently to the cascade of other neuropathological changes associated with the disease. Therefore, various therapeutic approaches are aimed to reduce the amount of $A \beta$-peptide including inhibition of $\beta$ - and $\gamma$-secretase activity, inhibition of toxic $A \beta$ fibrillation/ aggregation, and enhancing $A \beta$ clearance (Poduslo et al., 1999, Ghosh et al., 2002).

Recently, it has been shown that immune-mediated clearance pathways may have an important impact on plaque development in the brain (Schenk et al., 1999, Bard et al., 2000). It has been suggested that antibodies against $\mathrm{A} \beta$ could prevent amyloid deposition, ameliorate amyloid-mediated behavioral deterioration, and even clear existing plaques (Janus et al., 2000, Morgan et al., 2000). The A $\beta$ peripheral sink hypothesis was also made based on the finding that $A \beta$ can be transported out of brain when antibodies were mainly present in blood (DeMattos et al., 2002). As early as 1980, intravenous immunoglobulin (IVIG), an immune globulin product from human plasma, was used in the treatment of a variety of diseases (Fabian, 1980). A substantial amount of research has reported that there are abundant $A \beta$ autoantibodies in IVIG and these autoantibodies or IVIG may be effective for the treatment of AD and other neurodegenerative disorders (Dodel et al., 2002, Neff et al., 2008, Relkin et al., 2009, Dodel et al., 2010). Treatment with IVIG increased both CSF and serum levels of anti-A $\beta$ antibodies and significantly lowered CSF levels of $A \beta$ in AD patients, possibly by facilitating transport of $\mathrm{A} \beta$ from the CSF to the serum (Dodel et al., 2002). Most recently, clinical data demonstrated that IVIG treatments may slow down hypometabolic development in AD brains (Dodel et al., 2010). However, the mechanism underlying the IVIG-induced brain A $\beta$ efflux/clearance remains to be determined.

The blood-brain barrier (BBB) and blood-cerebrospinal fluid (CSF) barrier (BCB) are two brain barriers that separate the systemic blood circulation from the brain. The BBB is mainly composed of tightly connected cerebral capillary endothelial cells and prevents substances from leaving the blood and crossing the capillary walls into the brain tissues. Unlike the capillaries that form the BBB, the choroid plexus (CP), located within brain ventricles, tight junctions between the choroidal epithelial cells that seal one epithelium to another, constituting the BCB (Smith, 1991) that was thought to regulate efflux of molecules from CSF into the blood (Brown et al., 2004). It's been reported that $A \beta$ transports across the BBB into the brain from the systemic circulation via advanced glycation end-products (RAGE), while out of the brain via the low-density lipoprotein receptor-related protein (LRP)-1 (Deane et al., 2004, Donahue et al., 2006). Additionally, several studies have also shown A $\beta$ transports across the BCB (Sasaki et al., 1997, Monro et al., 2002, Serot et al., 2003, Crossgrove et al., 2005) and presents in the CP of AD patients (Kalaria et al., 1996). Since the CP is in direct continuity with the cerebral interstitial fluid (ISF) and the CSF, A $\beta$ in the brains extracellular space can freely enter into the CSF. Immunoreactive A $\beta$ and its 
precursor protein A $\beta P P$ in the CP (Sasaki et al., 1997, Crossgrove et al., 2007) suggests that the CP may be involved in the brains A $\beta$ clearance (Crossgrove et al., 2005, Behl et al., 2009a, Gu et al., 2011). Thus, it is interesting to explore the role of the BCB in the brain A $\beta$ clearance and IVIG-induced efflux of $A \beta$ from brains.

Low-density lipoprotein receptor-related protein 1 (LRP1) is a member of the LDL receptor family and has various unrelated functions; it participates in cholesterol and lipid transport, and plays a role in the clearance of extracellular proteases and proteinase complexes of apoptotic cells and debris. A $\beta$ binds to alpha-2-macroglobulin (A2M) and apolipoprotein $E$ (apoE). LRP1 serves as a receptor for these two proteins, and LRP1-mediated clearance of $\mathrm{A} 2 \mathrm{M}$ and apoE contributes to a reduction in A $\beta$ levels (Herz and Strickland, 2001). LRP1 may play a role in the BBB to transfer A $\beta$ from the brain to the blood (Kounnas et al., 1995, Knauer et al., 1996, Goto and Tanzi, 2002, Moir and Tanzi, 2005, Yamada et al., 2009). Recently, LRP1 was identified in the CP. Reduced LRP1 expression in the CP following lead $(\mathrm{Pb})$ treatments may be associated with $\mathrm{Pb}$-induced accumulation of $\mathrm{A} \beta$ in brain (Behl et al., 2009a, Gu et al., 2011). It was suggested that A $\beta$ elimination form CSF was possibly mediated by LRP1 expressed at the CP (Fujiyoshi et al., 2011). These evidences suggest that LRP1 may be involved in the IVIG-induced A $\beta$ clearance in the peripheral clearance system.

While much work has been done in immunization treatments for Alzheimer's disease and a peripheral sink hypothesis has been proposed extensively, the molecular mechanism underlying antibody-induced efflux of $A \beta$ from brain remains unclear. To address these questions, we used A $\beta P$ transgenic mice and an in vitro $B C B$ system to investigate whether IVIG could induce efflux of $A \beta$ from the brain through the BCB and if LRP1 mediated this process.

\section{Materials and methods}

\section{Animals and treatments}

An amyloid precursor protein (A $\beta \mathrm{PP})$ transgenic mouse model overexpressing human $\mathrm{A} \beta \mathrm{PP}$ with a mutation (V717F) that causes an autosomal dominant form of familial AD was utilized (Gu et al., 2011). In this study, 3 month old mice showed high levels of human A $\beta$ protein in brains without having plaques, which was consistent to previous reports demonstrating these mice had an age-related accumulation of $A \beta$ plaques in brains starting from 6 months of age (Bales et al., 1999). A $\beta P P$ transgenic mice (A $\beta P P$ V717F) (on a C57BL/6 genetic background) were bred in the Animal Center at Indiana University School of Medicine. Mice were housed 3-5 mice per cage, fed with food and water ad libitum, and maintained in a 12-h light/dark cycle facility. A group of 3 month old A $\beta P$ transgenic mice $(\mathrm{n}=6$ per group) were i.v. injected in the lateral tail vein with $500 \mu \mathrm{g}(20 \mathrm{mg} / \mathrm{kg})$ IVIG or IVIG in which anti-A $\beta$ antibodies had been depleted (IVIG w/o anti-A $\beta$ ) once a week for two weeks. Hippocampus, cortex, CSF and plasma samples were collected after two weeks treatment. Plasma was collected immediately after CSF was collected. Fresh samples were immediately tested afterward. Animal protocols pertinent to this study were approved by the Indiana University School of Medicine Laboratory Animal Resource Center. 


\section{Depletion of anti-A $\beta$ antibody from IVIG}

The protocol was adapted from a previously described method (Du et al., 2001, Du et al., 2003). The column was packed with NHS-sepharose 4B (Pharmacia Biotech, Piscataway, NJ) labeled with $A \beta_{1-40}$ (generous gifts from Eli Lilly, Indianapolis, IN, $0.6 \mathrm{mg} / \mathrm{ml}$ drained sepharose) and was equilibrated and washed with PBS (pH 7.4). After passing purified human IVIG (Bayer, Pittsburgh, PA) through the column, unbound fraction (IVIG w/o anti$\mathrm{A} \beta$ ) was collected.

\section{Culture of choroidal epithelial Z310 cells}

Z310 cells created by Dr. Wei Zheng is an immortalized rat choroidal epithelial cell line (Zheng and Zhao, 2002). Cells were cultured as previously described (Zheng and Zhao, 2002, Shi et al., 2008b). In brief, the cells were maintained in DMEM medium supplemented with $10 \%$ fetal bovine serum (FBS), $10 \mathrm{ng} / \mathrm{mL}$ epidermal growth factor (EGF), $100 \mathrm{U} / \mathrm{mL}$ of penicillin, $100 \mathrm{mg} / \mathrm{mL}$ of streptomycin and $40 \mathrm{mg} / \mathrm{mL}$ of gentamycin in a humidified incubator with $95 \%$ air and $5 \% \mathrm{CO}_{2}$ at $37^{\circ} \mathrm{C}$ and passaged twice a week.

\section{Inhibition of LRP1}

Z310 cells were pre-incubated with $100 \mathrm{nM}$ recombinant receptor-associated protein (RAP, EMD Millipore, Billerica, MA) for $1 \mathrm{hr}$ before the $\mathrm{A} \beta$ was added into the inner chamber. The LRP1 siRNA was obtained commercially from Sigma-Aldrich. The sequences of sense strand: Th- $5^{\prime}$-CCUAUCUUUGAGAUCCGAA-3' ; antisense strand: Th- $5^{\prime}$ UUCGGAUCUCAAAGAUAGG-3' (Behl et al., 2009a). Cells were seeded at a density of $1 \times 10^{5}$ cells/well in a 6-well plate in cell culture medium. After $24 \mathrm{~h}$, the RNA/transfection system was prepared as described in manufacturer's protocol: $3 \mu \mathrm{L}$ 10 $\mu \mathrm{M}$ siRNA was diluted in $500 \mu \mathrm{L}$ opti-MEM I (Invitrogen, Grand Island, NY). $5 \mu \mathrm{L}$ lipofectamine RNAiMAX (Invitrogen, Grand Island, NY) was added into the diluted siRNA and incubated for $20 \mathrm{~min}$ at room temperature. Cell culture medium was replaced with $500 \mu \mathrm{L}$ of the above mixture along with $2.5 \mathrm{~mL}$ of cell culture medium to obtain a total of $3 \mathrm{~mL}$ medium/well. The final concentration of siRNA was $10 \mathrm{nM}$. The solution containing siRNA was mixed gently by rocking the plate back and forth. Cells were transfected with scrambled siRNA as a negative control. Cells were grown for an additional $24 \mathrm{~h}$ and then cultured in the transwell transport device. After two days cell culture, $A \beta$ clearance experiment was performed. The knockdown efficiency was then analyzed by Western blot analysis.

\section{Determination of LRP1 and RAP Levels by Western Blot}

Mouse CP and Z310 cells were homogenized (1:10, wt/vol) on ice in RIPA buffer (SigmaAldrich, St. Louis, MO) with protease inhibitor cocktail (Roche, Indianapolis, IN). The protein concentration was determined by using the Bradford method. The protein extract (10 $\mu \mathrm{g}$ of protein) was loaded onto a 4-12\% Bis-Tris gel, electrophoresed, and then transferred to a nitrocellulose membrane. The blots were probed with antibody directly against LRP1 (1:20000, abcam, San Francisco, CA) or RAP (1:1000, abcam, San Francisco, CA), followed by a secondary antibody conjugated with horse-radish peroxidase (1:5000) and visualized by utilizing enhanced chemiluminescence. $\beta$-actin was also assayed as loading 
controls by using its antibody (1:1000, cell signaling, Danvers, MA). Band intensities were quantified and results were reported as a ratio of LRP1 to $\beta$-actin (Gu et al., 2011).

\section{Cultures in Transwell transport device}

The Transwell transport device is composed of two chambers which are separated by a porous polyester membrane insert (Costar, Corning, NY). Z310 cells were seeded on this membrane. The compartment in the insert is defined as the inner chamber. The lower compartment is defined as outer chamber. The cells possess tight barrier characteristics when cells are cultured on a permeable membrane (Shi and Zheng, 2005). A $\beta$ was added into the inner chamber and measured in the outer chamber. Prior to cell seeding on the porous polyester membrane within the inner chamber, the membrane was pre-coated with $0.01 \%$ collagen (Sigma, St. Louis, MO) for $4-5 \mathrm{hrs}$ at room temperature. $200 \mu \mathrm{L}$ aliquots of cell suspensions containing $5.0 \times 10^{4}$ cells were added to the inner chamber followed by addition of $500 \mu \mathrm{L}$ of the same culture medium into the outer chamber. A cell monolayer was usually formed 3-5 days after seeding. The media was refreshed every two days after seeding. The formation of cell monolayer was judged by three criteria: (1) the cells formed a confluent monolayer without visible spaces between cells under a light microscope; (2) the height of the culture medium in the inner chamber had to be at least $2 \mathrm{~mm}$ higher than that in the outer chamber for at least $24 \mathrm{hrs}$; and (3) a constant transepithelial electrical resistance (TEER) value across the cell layer was obtained $\left(61.3 \pm 2.62 \Omega . \mathrm{cm}^{2}\right)$ (Shi and Zheng, 2005). The TEER is a combination of the paracellular and transcellular flux of small inorganic ions (predominantly $\mathrm{Na}^{+}$and $\mathrm{Cl}^{-}$) across the monolayer. The latter contribution is commonly negligible due to the high lipid membrane resistance, but especially for monolayers with high paracellular tightness it may contribute to the measured TEER value (Fanning et al., 1999). The TEER value was measured using an epithelial volt-ohmmeter (EVOM, World Precision Instruments, Sarasota, FL) after culturing in Transwell chambers for at least 2 days. The net value was calculated by subtracting the background value, which was measured on a collagen-coated, cell free chamber (blank), from the value of cell-seeded chamber. The cultures that reached confluence were used in the transport studies. $1 \mu \mathrm{M}$ $\mathrm{A} \beta_{1-40}$ were added into the inner chamber media and the outer chamber media were collected at 1 and $3 \mathrm{hrs}$ following 10mg/ml IVIG and/or $100 \mathrm{nM}$ receptor-associated protein (RAP, EMD Millipore, Billerica, MA) or LRP1 siRNA treatments.

\section{Quantification of $A \beta$ and $A \beta$ antibody by ELISA}

Levels of $A \beta$ and $A \beta$ antibody were assayed by sandwich ELISA as described previously (Gu et al., 2012) (Hyslop and Bender, 2002). Hippocampus and cortex from mouse brain were extracted with $5 \mathrm{M}$ guanidine buffer. Tissues are homogenized at room temperature (RT) and nutated overnight at $4^{\circ} \mathrm{C}$. Samples were then diluted 1:10 with sample diluted buffer (1\% BSA with $0.05 \%$ Tween-20). Plasma, CSF samples, and culture media collected from out chamber were diluted 1:2 with diluted buffer. Mice samples, media collected from outer chamber, and the immunodepleted IVIG were processed in ninety-six-well ELISA plates that had been coated with antibody 266.2 (generous gifts from Eli Lilly, Indianapolis, IN) to determine $A \beta$ and $A \beta{ }_{1-40}$ to determine $A$ antibody. After incubation of plates with casein buffer $(0.25 \%$ casein and $0.05 \%$ sodium azide in PBS) for $2 \mathrm{hrs}$, samples were loaded overnight at $4{ }^{\circ} \mathrm{C}$. Biotin-3D6 (generous gifts from Eli Lilly, Indianapolis, IN) or biotin-anti- 
human $\operatorname{IgG}$ (Fc specific) (Sigma, St. Louis, Mo) was incubated for $1 \mathrm{hr}$ at room temperature, followed by horseradish peroxidase for $1 \mathrm{hr}$. After incubation with tetramethylbenzidine (TMB, Sigma, St. Louis, MO) the plates were read for absorbance at $450 \mathrm{~nm}$.

\section{Statistical analysis}

Statistical analyses of the differences between groups were carried out by a one-way ANOVA with post hoc comparisons by the Dunnett's test. All data are expressed as mean \pm SD. Differences between two means were considered significant when $p$ was equal or less than 0.05 .

\section{Results}

\section{IVIG reduced brain levels but increased blood levels of $A \beta_{\text {total }}$ in A $\beta P P$ transgenic mice}

To verify IVIG effect on $A \beta_{\text {total }}$ levels in $A \beta P P$ transgenic mice, we treated a group of 3 month old A $\beta P P$ transgenic mice ( $n=6$ per group) by i.v. administration with IVIG or IVIG w/o anti-A $\beta$ for 2 weeks. ELISA analyses showed that CSF concentrations of $A \beta_{\text {total }}$ in IVIG-treated mice after two-week treatments were significantly lower than mice treated with saline $(0.16 \pm 0.12 \mathrm{ng} / \mathrm{ml}$ versus $0.35 \pm 0.14 \mathrm{ng} / \mathrm{ml}$, respectively; $p<0.05)$ (Fig. 1A).

Additionally, two week-treatments of IVIG also significantly reduced $A \beta_{\text {total }}$ levels in the hippocampus $(0.03 \pm 0.01 \mathrm{ng} / \mathrm{mg}$ vs. $0.06 \pm 0.01 \mathrm{ng} / \mathrm{mg}, p<0.001)$ and cortex $(0.02 \pm 0.01 \mathrm{ng} / \mathrm{mg}$ vs. $0.04 \pm 0.01 \mathrm{ng} / \mathrm{mg}, p<0.05$ ), respectively, as compared to saline-treated mice (Fig. 1C.D). In contrast, plasma levels of $A \beta_{\text {total }}$ in one week-treated IVIG-treated mice were significantly increased as compared to saline-treated mice $(0.15 \pm 0.06 \mathrm{ng} / \mathrm{ml}$ versus $0.06 \pm 0.03 \mathrm{ng} / \mathrm{ml}, p<0.05$ ) (Fig.1B). As a control, treatments with IVIG w/o anti-A $\beta$ had little effect on both CSF and plasma levels of $A \beta_{\text {total }}$ in transgenic mice as compared to control (Fig.1). We detected human anti-A $\beta$ antibodies in mice after IVIG treatment. The $\mathrm{CSF}$ and plasma levels of human anti-A $\beta$ antibodies were $2.5 \pm 3.3 \mathrm{pg} / \mathrm{ml}$ and $289.3 \pm 41.5$ $\mathrm{ng} / \mathrm{ml}$. Human anti-A $\beta$ antibodies were not detected in IVIG w/o anti-A $\beta$ treated mice.

\section{CP Levels of LRP1 and RAP in IVIG treated mice}

IVIG reduced $A \beta_{\text {total }}$ levels in APP transgenic mice brains may result from IVIG affected LRP1 and/or RAP levels in the CP. LRP1 and RAP in the CP were determined by Western blot. Our results demonstrated that there is no difference between CP levels of LRP1 and RAP in IVIG treated mice with control mice (Fig.2).

\section{Transepithelial electrical resistance (TEER) values of $Z 310$ cells in the in vitro BCB model}

To specifically examine the role of the $\mathrm{CP}$ in the regulation of $\mathrm{A} \beta$ efflux from brain following treatments of IVIG, we used a well-established in vitro brain barrier epithelial transport system that had been widely used for BCB studies (Zheng and Zhao, 2002, Shi and Zheng, 2005, Shi et al., 2008b, Wang et al., 2008). Z310 cells were grown in the transwell chamber culture system to form a confluent membrane that possessed tight barrier characteristics as choroid plexus (Shi and Zheng, 2005). The tightness of the barrier between two chambers were measured by the TEER after a 2 day culture in Transwell chambers and TEER could reach $63.9 \pm 0.85 \Omega . \mathrm{cm}^{2}$ at day 3 and day 4 in this study (Fig. 3A), was comparable to the $61.3 \pm 2.62 \Omega . \mathrm{cm}^{2}$ reported in the previous report (Shi and Zheng, 2005). 
To test whether IVIG and A $\beta$ affect the rigidity of cell monolayer, TEER was measured before and after IVIG and $A \beta$ treatments. There was little change between treated and untreated samples (Fig. 3B).

\section{IVIG induced $A \beta$ efflux from inner chamber}

$1 \mu \mathrm{M} \mathrm{A} \beta_{1-40}$ were added into the inner chamber media and the outer media were collected at 1 and 3 hrs following treatments. This dose regimen was shown to produce a significant accumulation of $\mathrm{A} \beta$ in $\mathrm{Z} 310$ cells in our previous studies (Behl et al., 2009a, Behl et al., $2009 \mathrm{~b}$ ) and in vitro toxicity studies (Shabala et al., 2010). A $\beta$ concentrations in outer chamber were gradually increased from 0 into $0.28 \pm 0.06 \mathrm{ng} / \mathrm{ml}$ at $1 \mathrm{hr}$ and $4.2 \pm 0.96 \mathrm{ng} / \mathrm{ml}$ at $3 \mathrm{hrs}$ following treatments. Furthermore, addition of IVIG into the outer chamber markedly increased amounts of $\mathrm{A} \beta$ efflux from inner chambers from $0.28 \pm 0.06 \mathrm{ng} / \mathrm{ml}$ to $2.52 \pm 0.22 \mathrm{ng} / \mathrm{ml}$ at $1 \mathrm{hr}(p<0.001)$ and $4.2 \pm 0.96 \mathrm{ng} / \mathrm{ml}$ to $7.61 \pm 0.91 \mathrm{ng} / \mathrm{ml}$ at $3 \mathrm{hrs}(p<0.001)$ of treatments (Fig. 4A).

\section{Low Density Lipoprotein Receptor-related Protein (RAP) partially inhibited efflux of A $\beta$ from inner chamber}

We next examined whether LRP1 was involved in A $\beta$ efflux with or without IVIG induction. $100 \mathrm{nM}$ RAP, an inhibitor of LRP1 or saline, were added into the inner chamber for $1 \mathrm{hr}$ followed by the addition of $1 \mu \mathrm{M} \mathrm{A} \beta$. Without IVIG treatments, $A \beta$ concentrations in outer chamber were dramatically reduced by RAP from $0.28 \pm 0.06 \mathrm{ng} / \mathrm{ml}$ to $0.02 \pm 0.01$ $\mathrm{ng} / \mathrm{ml} 1 \mathrm{hr}$ after $A \beta$ treatments and $4.2 \pm 0.96 \mathrm{ng} / \mathrm{ml}$ to $1.12 \pm 0.51 \mathrm{ng} / \mathrm{ml} 3 \mathrm{hrs}$ after $\mathrm{A} \beta$ treatments $(\mathrm{p}<0.001)$. Furthermore, RAP treatments also significantly blocked IVIG-induced $\mathrm{A} \beta$ efflux from inner chambers $1 \mathrm{hr}$ (from $2.52 \pm 0.22 \mathrm{ng} / \mathrm{ml}$ to $1.77 \pm 0.1 \mathrm{ng} / \mathrm{ml}, p<0.001$ ) and $3 \mathrm{hrs}$ (from $7.61 \pm 0.91 \mathrm{ng} / \mathrm{ml}$ to $5.41 \pm 0.92 \mathrm{ng} / \mathrm{ml}, p<0.001$ ) (Fig. 4B).

\section{LRP1 knockdown by siRNA partially inhibited efflux of $A \beta$ from inner chamber}

To test whether $A \beta$ efflux following IVIG exposure was indeed mediated by LRP1 in the $B C B$, we assessed $A \beta$ efflux in vitro BCB model following LRP1 knockdown by siRNA. The knockdown efficiency was analyzed by Western blot analysis. As shown in data presented in Fig. 5, introducing LRP1 siRNA to the cells caused a significant reduction of LRP1 at protein $(84.7 \%)$ expression levels as compared to the scrambled siRNA controls (Fig. 5A, B). Following LRP1 knockdown by siRNA, the Z310 cells were then divided into four groups (Fig. 5C): scrambled siRNA control without IVIG treatment, LRP1 knockdown control without IVIG treatment, scrambled siRNA control with IVIG treatment, and LRP1 knockdown cells with IVIG exposure. $1 \mu \mathrm{M}$ A $\beta$ were added into the inner chamber. A $\beta$ concentrations in outer chamber were quantified as before using ELISA. Without IVIG treatments, $A \beta$ concentrations in outer chamber were reduced by LRP1 knockdown from $0.28 \pm 0.08 \mathrm{ng} / \mathrm{ml}$ to $0.02 \pm 0.004 \mathrm{ng} / \mathrm{ml} 1 \mathrm{hr}$ after $A \beta$ added and $4.0 \pm 0.31 \mathrm{ng} / \mathrm{ml}$ to $1.17 \pm 0.38$ $\mathrm{ng} / \mathrm{ml} 3$ hrs after $A \beta$ added ( $<0.05)$. Furthermore, after LRP1 was knocked down and followed by IVIG treatment, IVIG-induced A $\beta$ efflux from inner chambers were reduced from $2.39 \pm 0.51 \mathrm{ng} / \mathrm{ml}$ to $1.1 \pm 0.28 \mathrm{ng} / \mathrm{ml}$ after $1 \mathrm{hr} A \beta$ added $(p<0.001)$ and $7.26 \pm 1.14 \mathrm{ng} / \mathrm{ml}$ to $2.86 \pm 0.86 \mathrm{ng} / \mathrm{ml}$ after $3 \mathrm{hrs} \mathrm{A} \beta$ added ( $p<0.001$ ) (Fig. 5C). These results support the 
hypothesis that increased efflux of A $\beta$ may be mediated at least in part by IVIG effect on LRP1.

\section{Discussion}

IVIG has been clinically used to treat a variety of diseases (Fabian, 1980) and currently, at least two clinical trials are performed to examine whether IVIG could be used to treat AD. (Dodel et al., 2002, Neff et al., 2008, Relkin et al., 2009, Dodel et al., 2010). We have identified anti-A $\beta$ autoantibodies ( $(\mathrm{IgG})$ in human serum and CSF that may act in an immune-mediated $A \beta$ clearance pathway (Du et al., 2001, Dodel et al., 2002). Our early report demonstrated that treatments with IVIG dramatically increased serum levels of $A \beta$ and significantly lowered CSF levels of $\mathrm{A} \beta$ in $\mathrm{AD}$ and Multiple Sclerosis patients, possibly by facilitating the transport of $A \beta$ from the CSF to the serum by its contained anti-A $\beta$ autoantibodies (Dodel et al., 2002). However, the molecular mechanism underlying IVIGinduced efflux of $\mathrm{A} \beta$ from brain remains unknown. The studies presented in this report took the advantage of the A $\beta P P$ transgenic mice, which specifically overexpress $A \beta$ in brain. Similar to our human studies, mouse data clearly show that after one week treatment with IVIG containing $A \beta$ autoantibodies, the plasma level of $A \beta_{\text {total }}$ was dramatically higher in IVIG-treated mice than the saline-treated and IVIG w/o anti-A $\beta$-treated mice. In contrast, two weeks of IVIG treatments significantly decreased brain and CSF levels of $A \beta_{\text {total }}$. The activities of anti- $A \beta$ in the IVIG and IVIG without anti-A $\beta$ antibodies were detected by ELISA (Dodel et al., 2002, Du et al., 2003). Naturally occurring antibodies directed againstamyloid were detected in IVIG. There was a strong signal in IVIG, however, no signal detected in the IVIG without anti-A $\beta$ antibodies. There was little difference in levels of A $\beta$ between IVIG w/o anti-A $\beta$ group and saline-treated group, suggesting that $A \beta$ autoantibodies in IVIG may play a key role in inducing efflux of $A \beta$ from the brain into blood.

Since the BCB is a major mechanism mediating efflux of molecules from CSF to blood, we used an established in vitro BCB model (Zheng and Zhao, 2002, Shi and Zheng, 2005, Shi et al., 2008a) to investigate if and how the BCB was involved in IVIG-induced A $\beta$ mobilization from brain. Additionally, as LRP1 was reported to possibly contribute to the regulation of $\mathrm{A} \beta$ mobilization in the $\mathrm{BCB}$, we used RAP, a specific LRP1 receptor antagonist, to further confirm the role of the $\mathrm{BCB}$ in $\mathrm{A} \beta$ efflux. It was reported that RAP could bind $\mathrm{A} \beta$ at above $500 \mathrm{nM}$ (Kanekiyo and $\mathrm{Bu}, 2009$ ), therefore in this study, we used $100 \mathrm{nM}$ at which RAP was demonstrated to show little binding affinity to $\mathrm{A} \beta$ and still could significantly block LRP1 function (Shakibaei and Frevert, 1996, Hayashi et al., 2009). As expected, RAP significantly blocked both basal and IVIG-induced A $\beta$ efflux from inner to outer chambers. For further confirmation, we performed LRP1 knockdown experiments by using LRP1 siRNA. The results revealed that inhibition of LRP1 expression significantly reduced basal and IVIG-induced A $\beta$ efflux. These results suggest that LRP1 should play an important role in regulating $A \beta$ mobilization in this in vitro $B C B$ model. Results reveal that IVIG did induce $A \beta$ efflux through the LRP1 receptor in BCB cells. Our data suggests that the choroid plexus played an important role in removing $A \beta$ from the brain during IVIG treatments and LRP1 in the BCB was specifically involved at least partially, if not completely, in this process. Interestingly enough, two AD risk factors, apolipoprotein $\mathrm{E}$ and 
alpha2-macroglobulin, are agonists for LRP1 receptor and they may affect IVIG- and other anti-A $\beta$ antibody-involved therapy.

In our previous study, we found that $\mathrm{A} \beta$ autoantibodies in IVIG were mainly present in the blood after i.v. injection (Bacher et al., 2009). Similar to studies using A $\beta$-antibody 266 (DeMattos RB et al., 2002), A $\beta$ autoantibodies in IVIG induced A $\beta$ efflux across the CP from brains into bloods also possibly by the sink mechanism. Additionally, as suggested by Yamada et al who reported that only soluble free $A \beta$, not the 266 antibody complexed with A $\beta$ might move throung the LRP1 in the CP (Yamada et al., 2009), A $\beta$ complexed with IVIG in peripheral also prevented transport of $A \beta$ back into the brain that could further enhace A $\beta$ efflex. Furthermore, we found that CP levels of both LRP1 and RAP were not affected by in vivo IVIG treatments indicating that binding between IVIG and A $\beta$ in peripheral might be the major force to induce $A \beta$ efflux out of brains.

It should be noted that blockade of LRP1 only partially inhibited $A \beta$ efflux across the BCB indicating other transport mechanisms may also be involved in IVIG-induced $\mathrm{A} \beta$ efflux. Pglycoprotein (P-gp), an ATP-driven efflux transporter in the CP, was reported to be involved in $A \beta$ clearance from the brain (Hartz et al., 2010, Pascale et al., 2011). Additionally, there are other receptors that help transport $\mathrm{A} \beta$ from the CSF into the $\mathrm{CP}$ epithelium, such as the RAGE and the low density lipoprotein receptor-related protein 2 (LRP-2) (Pascale et al., 2011). Both receptors were localized in the $C P$ and linked to $A \beta$ transport form CSF into the CP cells (Maslinska et al., 2011, Pascale et al., 2011) (Hammad et al., 1997). Therefore, further studies regarding on roles of other transporters/receptors in IVIG-induced A $\beta$ efflux are necessary.

\section{Acknowledgments}

This research is supported by a grant from NIH/NIEHS (R21 ES017055). No conflict of interest.

\section{References}

Bacher M, Depboylu C, Du Y, Noelker C, Oertel WH, Behr T, Henriksen G, Behe M, Dodel R. Peripheral and central biodistribution of (111)In-labeled anti-beta-amyloid autoantibodies in a transgenic mouse model of Alzheimer's disease. Neuroscience letters. 2009; 449:240-245. [PubMed: 18786612]

Bales KR, Verina T, Cummins DJ, Du Y, Dodel RC, Saura J, Fishman CE, DeLong CA, Piccardo P, Petegnief V, Ghetti B, Paul SM. Apolipoprotein E is essential for amyloid deposition in the APP(V717F) transgenic mouse model of Alzheimer's disease. Proceedings of the National Academy of Sciences of the United States of America. 1999; 96:15233-15238. [PubMed: 10611368]

Bard F, Cannon C, Barbour R, Burke RL, Games D, Grajeda H, Guido T, Hu K, Huang J, JohnsonWood K, Khan K, Kholodenko D, Lee M, Lieberburg I, Motter R, Nguyen M, Soriano F, Vasquez N, Weiss K, Welch B, Seubert P, Schenk D, Yednock T. Peripherally administered antibodies against amyloid beta-peptide enter the central nervous system and reduce pathology in a mouse model of Alzheimer disease. Nature medicine. 2000; 6:916-919.

Behl M, Zhang Y, Monnot AD, Jiang W, Zheng W. Increased beta-amyloid levels in the choroid plexus following lead exposure and the involvement of low-density lipoprotein receptor protein-1. Toxicology and applied pharmacology. 2009a; 240:245-254. [PubMed: 19501112] 
Behl M, Zhang Y, Zheng W. Involvement of insulin-degrading enzyme in the clearance of betaamyloid at the blood-CSF barrier: Consequences of lead exposure. Cerebrospinal fluid research. 2009b; 6:11. [PubMed: 19747378]

Brown PD, Davies SL, Speake T, Millar ID. Molecular mechanisms of cerebrospinal fluid production. Neuroscience. 2004; 129:957-970. [PubMed: 15561411]

Crossgrove JS, Li GJ, Zheng W. The choroid plexus removes beta-amyloid from brain cerebrospinal fluid. Exp Biol Med (Maywood). 2005; 230:771-776. [PubMed: 16246905]

Crossgrove JS, Smith EL, Zheng W. Macromolecules involved in production and metabolism of betaamyloid at the brain barriers. Brain Res. 2007; 1138:187-195. [PubMed: 17276414]

Deane R, Wu Z, Sagare A, Davis J, Du Yan S, Hamm K, Xu F, Parisi M, LaRue B, Hu HW, Spijkers P, Guo H, Song X, Lenting PJ, Van Nostrand WE, Zlokovic BV. LRP/amyloid beta-peptide interaction mediates differential brain efflux of Abeta isoforms. Neuron. 2004; 43:333-344. [PubMed: 15294142]

DeMattos RB, Bales KR, Cummins DJ, Paul SM, Holtzman DM. Brain to plasma amyloid-beta efflux: a measure of brain amyloid burden in a mouse model of Alzheimer's disease. Science. 2002; 295:2264-2267. [PubMed: 11910111]

Dodel R, Hampel H, Depboylu C, Lin S, Gao F, Schock S, Jackel S, Wei X, Buerger K, Hoft C, Hemmer B, Moller HJ, Farlow M, Oertel WH, Sommer N, Du Y. Human antibodies against amyloid beta peptide: a potential treatment for Alzheimer's disease. Annals of neurology. 2002; 52:253-256. [PubMed: 12210803]

Dodel R, Neff F, Noelker C, Pul R, Du Y, Bacher M, Oertel W. Intravenous immunoglobulins as a treatment for Alzheimer's disease: rationale and current evidence. Drugs. 2010; 70:513-528. [PubMed: 20329802]

Donahue JE, Flaherty SL, Johanson CE, Duncan JA 3rd, Silverberg GD, Miller MC, Tavares R, Yang W, Wu Q, Sabo E, Hovanesian V, Stopa EG. RAGE, LRP-1, and amyloid-beta protein in Alzheimer's disease. Acta neuropathologica. 2006; 112:405-415. [PubMed: 16865397]

Du Y, Dodel R, Hampel H, Buerger K, Lin S, Eastwood B, Bales K, Gao F, Moeller HJ, Oertel W, Farlow M, Paul S. Reduced levels of amyloid beta-peptide antibody in Alzheimer disease. Neurology. 2001; 57:801-805. [PubMed: 11552007]

Du Y, Wei X, Dodel R, Sommer N, Hampel H, Gao F, Ma Z, Zhao L, Oertel WH, Farlow M. Human anti-beta-amyloid antibodies block beta-amyloid fibril formation and prevent beta-amyloidinduced neurotoxicity. Brain : a journal of neurology. 2003; 126:1935-1939. [PubMed: 12821522]

Fabian T. [Prof. Imre Vamos, DDS. 1928-1980]. Fogorv Sz. 1980; 73:193-194. [PubMed: 6998749]

Fanning AS, Mitic LL, Anderson JM. Transmembrane proteins in the tight junction barrier. Journal of the American Society of Nephrology : JASN. 1999; 10:1337-1345. [PubMed: 10361874]

Fujiyoshi M, Tachikawa M, Ohtsuki S, Ito S, Uchida Y, Akanuma S, Kamiie J, Hashimoto T, Hosoya K, Iwatsubo T, Terasaki T. Amyloid-beta peptide(1-40) elimination from cerebrospinal fluid involves low-density lipoprotein receptor-related protein 1 at the blood-cerebrospinal fluid barrier. Journal of neurochemistry. 2011; 118:407-415. [PubMed: 21585370]

Ghosh AK, Hong L, Tang J. Beta-secretase as a therapeutic target for inhibitor drugs. Curr Med Chem. 2002; 9:1135-1144. [PubMed: 12052177]

Goto JJ, Tanzi RE. The role of the low-density lipoprotein receptor-related protein (LRP1) in Alzheimer's A beta generation: development of a cell-based model system. Journal of molecular neuroscience : MN. 2002; 19:37-41. [PubMed: 12212791]

Gu H, Robison G, Hong L, Barrea R, Wei X, Farlow MR, Pushkar YN, Du Y, Zheng W. Increased beta-amyloid deposition in Tg-SWDI transgenic mouse brain following in vivo lead exposure. Toxicology letters. 2012; 213:211-219. [PubMed: 22796588]

Gu H, Wei X, Monnot AD, Fontanilla CV, Behl M, Farlow MR, Zheng W, Du Y. Lead exposure increases levels of beta-amyloid in the brain and CSF and inhibits LRP1 expression in APP transgenic mice. Neuroscience letters. 2011; 490:16-20. [PubMed: 21167913]

Hammad SM, Ranganathan S, Loukinova E, Twal WO, Argraves WS. Interaction of apolipoprotein Jamyloid beta-peptide complex with low density lipoprotein receptor-related protein- $2 / m e g a l i n$. A mechanism to prevent pathological accumulation of amyloid beta-peptide. The Journal of biological chemistry. 1997; 272:18644-18649. [PubMed: 9228033] 
Hartz AM, Miller DS, Bauer B. Restoring blood-brain barrier P-glycoprotein reduces brain amyloidbeta in a mouse model of Alzheimer's disease. Molecular pharmacology. 2010; 77:715-723. [PubMed: 20101004]

Hayashi S, Yamamoto M, Tachibana K, Ueno Y, Bu G, Fukushima T. Mechanism of photofrinenhanced ultrasound-induced human glioma cell death. Anticancer Res. 2009; 29:897-905. [PubMed: 19414325]

Herz J, Strickland DK. LRP: a multifunctional scavenger and signaling receptor. J Clin Invest. 2001; 108:779-784. [PubMed: 11560943]

Hyslop PA, Bender MH. Methods for sample preparation for direct immunoassay measurement of analytes in tissue homogenates: ELISA assay of amyloid beta-peptides. Curr Protoc Neurosci. 2002 Chapter 7:Unit 720.

Janus C, Pearson J, McLaurin J, Mathews PM, Jiang Y, Schmidt SD, Chishti MA, Horne P, Heslin D, French J, Mount HT, Nixon RA, Mercken M, Bergeron C, Fraser PE, St George-Hyslop P, Westaway D. A beta peptide immunization reduces behavioural impairment and plaques in a model of Alzheimer's disease. Nature. 2000; 408:979-982. [PubMed: 11140685]

Kalaria RN, Premkumar DR, Pax AB, Cohen DL, Lieberburg I. Production and increased detection of amyloid beta protein and amyloidogenic fragments in brain microvessels, meningeal vessels and choroid plexus in Alzheimer's disease. Brain Res Mol Brain Res. 1996; 35:58-68. [PubMed: 8717340]

Kanekiyo T, Bu G. Receptor-associated protein interacts with amyloid-beta peptide and promotes its cellular uptake. J Biol Chem. 2009; 284:33352-33359. [PubMed: 19826010]

Knauer MF, Orlando RA, Glabe CG. Cell surface APP751 forms complexes with protease nexin 2 ligands and is internalized via the low density lipoprotein receptor-related protein (LRP). Brain research. 1996; 740:6-14. [PubMed: 8973792]

Kounnas MZ, Moir RD, Rebeck GW, Bush AI, Argraves WS, Tanzi RE, Hyman BT, Strickland DK. LDL receptor-related protein, a multifunctional ApoE receptor, binds secreted beta-amyloid precursor protein and mediates its degradation. Cell. 1995; 82:331-340. [PubMed: 7543026]

Maslinska D, Laure-Kamionowska M, Taraszewska A, Deregowski K, Maslinski S. Immunodistribution of amyloid beta protein (Abeta) and advanced glycation end-product receptors (RAGE) in choroid plexus and ependyma of resuscitated patients. Folia neuropathologica / Association of Polish Neuropathologists and Medical Research Centre, Polish Academy of Sciences. 2011; 49:295-300.

Moir RD, Tanzi RE. LRP-mediated clearance of Abeta is inhibited by KPI-containing isoforms of APP. Current Alzheimer research. 2005; 2:269-273. [PubMed: 15974929]

Monro OR, Mackic JB, Yamada S, Segal MB, Ghiso J, Maurer C, Calero M, Frangione B, Zlokovic BV. Substitution at codon 22 reduces clearance of Alzheimer's amyloid-beta peptide from the cerebrospinal fluid and prevents its transport from the central nervous system into blood. Neurobiol Aging. 2002; 23:405-412. [PubMed: 11959403]

Morgan D, Diamond DM, Gottschall PE, Ugen KE, Dickey C, Hardy J, Duff K, Jantzen P, DiCarlo G, Wilcock D, Connor K, Hatcher J, Hope C, Gordon M, Arendash GW. A beta peptide vaccination prevents memory loss in an animal model of Alzheimer's disease. Nature. 2000; 408:982-985. [PubMed: 11140686]

Neff F, Wei X, Nolker C, Bacher M, Du Y, Dodel R. Immunotherapy and naturally occurring autoantibodies in neurodegenerative disorders. Autoimmun Rev. 2008; 7:501-507. [PubMed: 18558370]

Ogomori K, Kitamoto T, Tateishi J, Sato Y, Suetsugu M, Abe M. Beta-protein amyloid is widely distributed in the central nervous system of patients with Alzheimer's disease. Am J Pathol. 1989; 134:243-251. [PubMed: 2464938]

Pascale CL, Miller MC, Chiu C, Boylan M, Caralopoulos IN, Gonzalez L, Johanson CE, Silverberg GD. Amyloid-beta transporter expression at the blood-CSF barrier is age-dependent. Fluids and barriers of the CNS. 2011; 8:21. [PubMed: 21740544]

Poduslo JF, Curran GL, Kumar A, Frangione B, Soto C. Beta-sheet breaker peptide inhibitor of Alzheimer's amyloidogenesis with increased blood-brain barrier permeability and resistance to proteolytic degradation in plasma. J Neurobiol. 1999; 39:371-382. [PubMed: 10363910] 
Relkin NR, Szabo P, Adamiak B, Burgut T, Monthe C, Lent RW, Younkin S, Younkin L, Schiff R, Weksler ME. 18-Month study of intravenous immunoglobulin for treatment of mild Alzheimer disease. Neurobiol Aging. 2009; 30:1728-1736. [PubMed: 18294736]

Sasaki A, Iijima M, Yokoo H, Shoji M, Nakazato Y. Human choroid plexus is an uniquely involved area of the brain in amyloidosis: a histochemical, immunohistochemical and ultrastructural study. Brain Res. 1997; 755:193-201. [PubMed: 9175887]

Schenk D, Barbour R, Dunn W, Gordon G, Grajeda H, Guido T, Hu K, Huang J, Johnson-Wood K, Khan K, Kholodenko D, Lee M, Liao Z, Lieberburg I, Motter R, Mutter L, Soriano F, Shopp G, Vasquez N, Vandevert C, Walker S, Wogulis M, Yednock T, Games D, Seubert P. Immunization with amyloid-beta attenuates Alzheimer-disease-like pathology in the PDAPP mouse. Nature. 1999; 400:173-177. [PubMed: 10408445]

Serot JM, Bene MC, Faure GC. Choroid plexus, aging of the brain, and Alzheimer's disease. Front Biosci. 2003; 8:s515-521. [PubMed: 12700093]

Shabala L, Howells C, West AK, Chung RS. Prolonged Abeta treatment leads to impairment in the ability of primary cortical neurons to maintain $\mathrm{K}+$ and $\mathrm{Ca} 2+$ homeostasis. Molecular neurodegeneration. 2010; 5:30. [PubMed: 20704753]

Shakibaei M, Frevert U. Dual interaction of the malaria circumsporozoite protein with the low density lipoprotein receptor-related protein (LRP) and heparan sulfate proteoglycans. J Exp Med. 1996; 184:1699-1711. [PubMed: 8920859]

Shi LZ, Li GJ, Wang S, Zheng W. Use of Z310 cells as an in vitro blood-cerebrospinal fluid barrier model: tight junction proteins and transport properties. Toxicology in vitro : an international journal published in association with BIBRA. 2008a; 22:190-199. [PubMed: 17825520]

Shi LZ, Li GJ, Wang SZ, Zheng W. Use of Z310 cells as an in vitro blood-cerebro spinal fluid barrier model: Tight junction proteins and transport properties. Toxicol in Vitro. 2008b; 22:190-199. [PubMed: 17825520]

Shi LZ, Zheng W. Establishment of an in vitro brain barrier epithelial transport system for pharmacological and toxicological study. Brain research. 2005; 1057:37-48. [PubMed: 16126179]

Smith QR. The blood-brain barrier and the regulation of amino acid uptake and availability to brain. Adv Exp Med Biol. 1991; 291:55-71. [PubMed: 1927691]

Wang X, Li GJ, Zheng W. Efflux of iron from the cerebrospinal fluid to the blood at the blood-CSF barrier: effect of manganese exposure. Exp Biol Med (Maywood). 2008; 233:1561-1571. [PubMed: 18849539]

Yamada K, Yabuki C, Seubert P, Schenk D, Hori Y, Ohtsuki S, Terasaki T, Hashimoto T, Iwatsubo T. Abeta immunotherapy: intracerebral sequestration of Abeta by an anti-Abeta monoclonal antibody 266 with high affinity to soluble Abeta. The Journal of neuroscience : the official journal of the Society for Neuroscience. 2009; 29:11393-11398. [PubMed: 19741145]

Zheng W, Zhao Q. Establishment and characterization of an immortalized Z310 choroidal epithelial cell line from murine choroid plexus. Brain research. 2002; 958:371-380. [PubMed: 12470873] 


\section{Highlights}

- IVIG reduces brain $A \beta$ levels.

- IVIG induces $A \beta$ efflux through the in-vitro $B C B$ membrane.

- $\quad$ RAP and LRP1 siRNA significantly inhibits $A \beta$ efflux. 

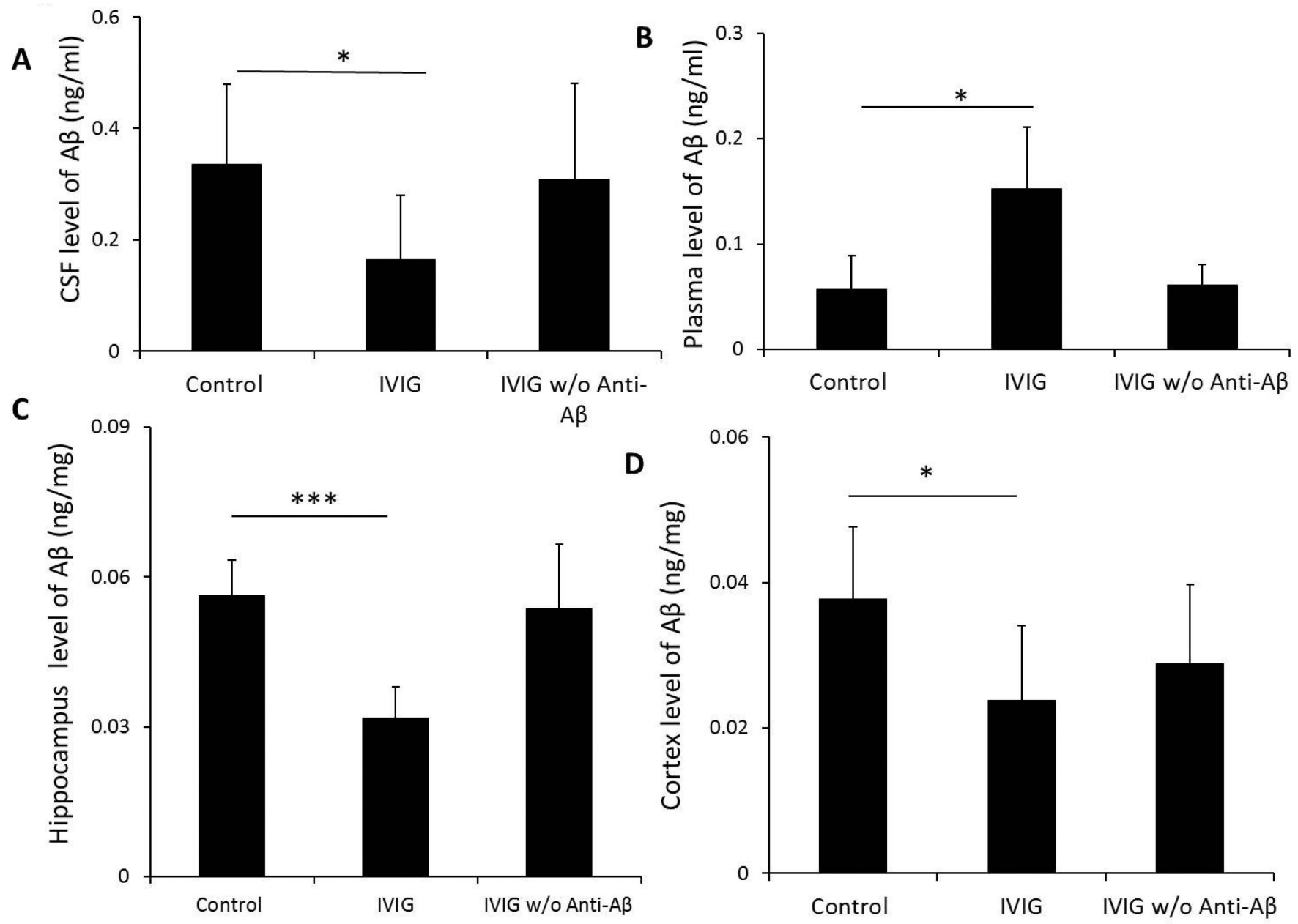

Fig. 1.

IVIG treatment decreased brain levels but increased plasma level of $A \beta_{\text {total }} .3$ month old A $\beta P P$ transgenic mice received i.v. administration of $0.5 \mathrm{mg} / \mathrm{kg}$ as IVIG or IVIG w/o antiA $\beta$ weekly for 2 weeks. CSF (A), plasma (B), hippocampus (C), and cortex (D), levels of $\mathrm{A} \beta_{\text {total }}$ in control, IVIG-treated, and IVIG that anti-A $\beta$ autoantibodies has been removed (IVIG w/o anti-A $\beta$ ) groups were determined by ELISA. Data represent mean $\pm \mathrm{SD}, \mathrm{n}=6$. *: $\mathrm{p}<0.05, * * *: \mathrm{p}<0.001$. 
A

B

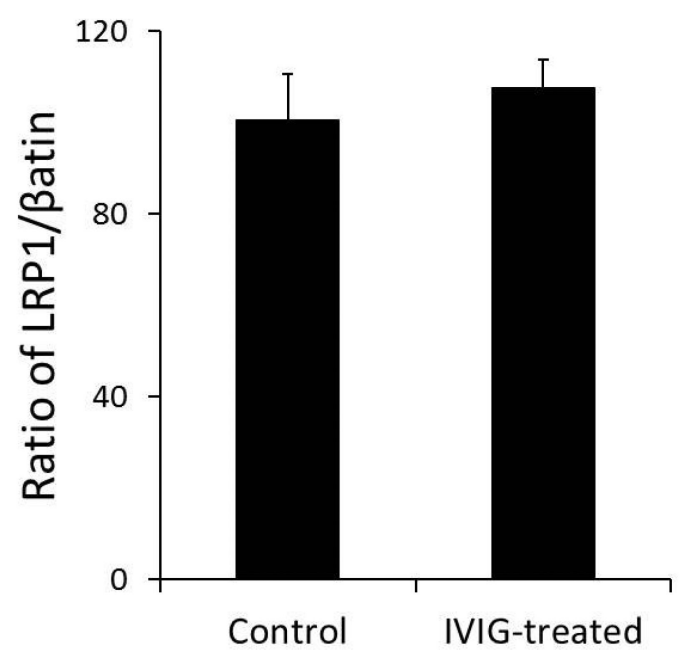

Fig. 2.
C
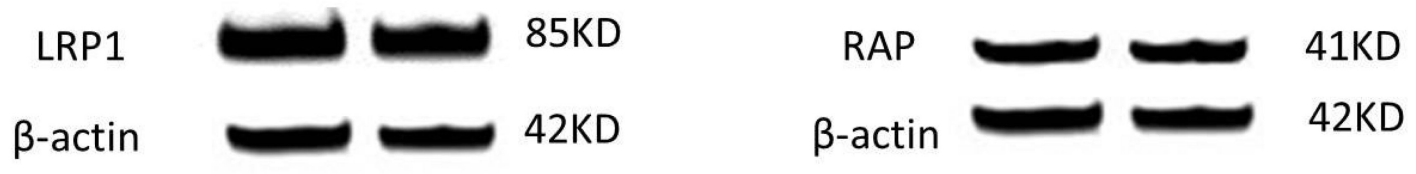

D

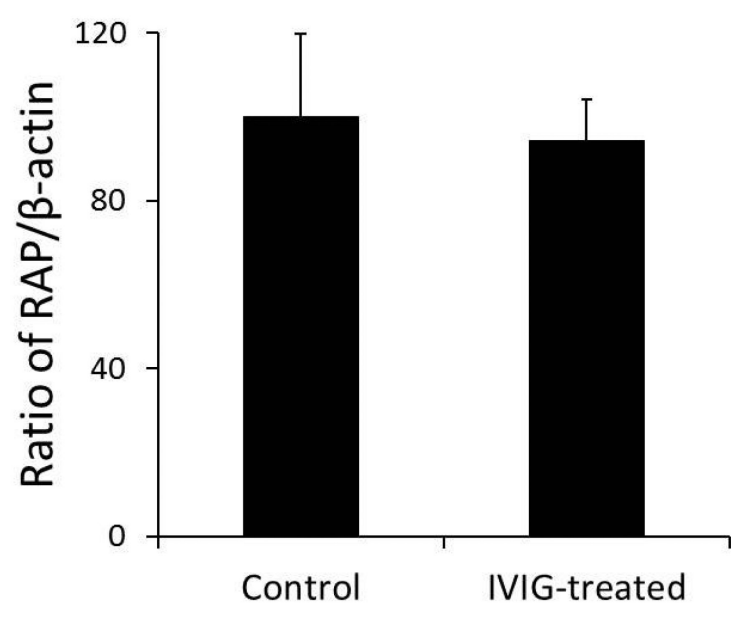

IVIG treatment didn't affect CP levels of LRP1 and RAP. 3 month old AßPP transgenic mice received i.v. administration of $0.5 \mathrm{mg} / \mathrm{kg}$ as IVIG or IVIG w/o anti-A $\beta$. After 24 hours, mouse CPs were collected and CP levels of LRP1 and RAP were measured by Western blot analysis. Data represent mean $\pm \mathrm{SD}, \mathrm{n}=3$. 
A
B

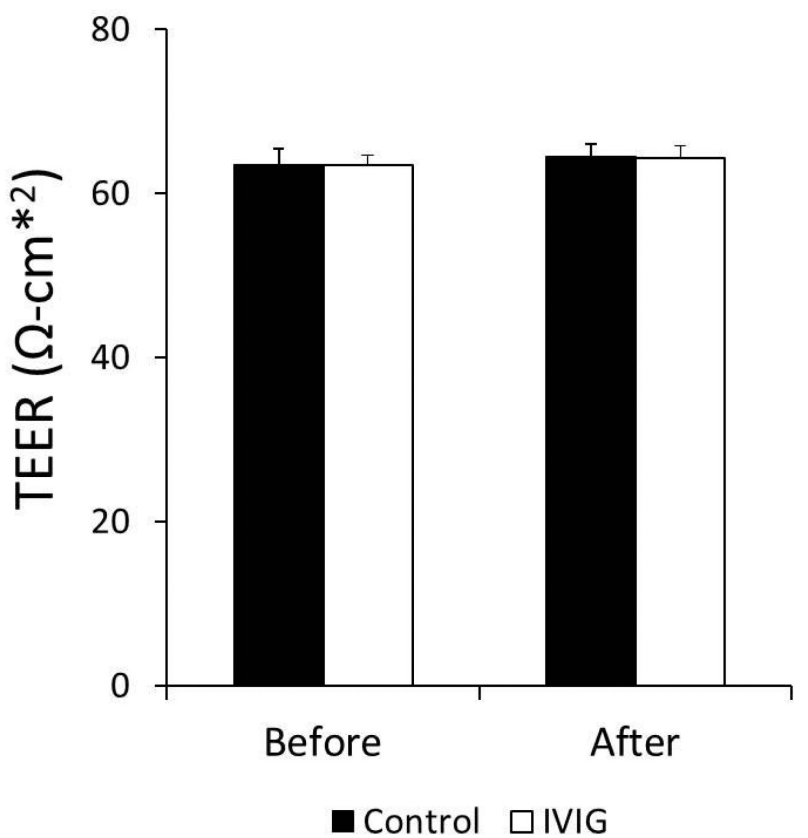

Fig. 3.

Transepithelial electrical resistance (TEER) values of Z310 cells in the in vitro BCB model. TEER values across the transwell chamber culture system were determined from day 2 to day 4. TEER values reached $63.9 \pm 0.85 \Omega . \mathrm{cm}^{2}$ on day 3 (A). Before and after $3 \mathrm{hrs}$ incubation with $\mathrm{A} \beta$, TEER values were measured and no difference detected (B). Data represent mean \pm SD of three independent experiments, $n=3$. 
A

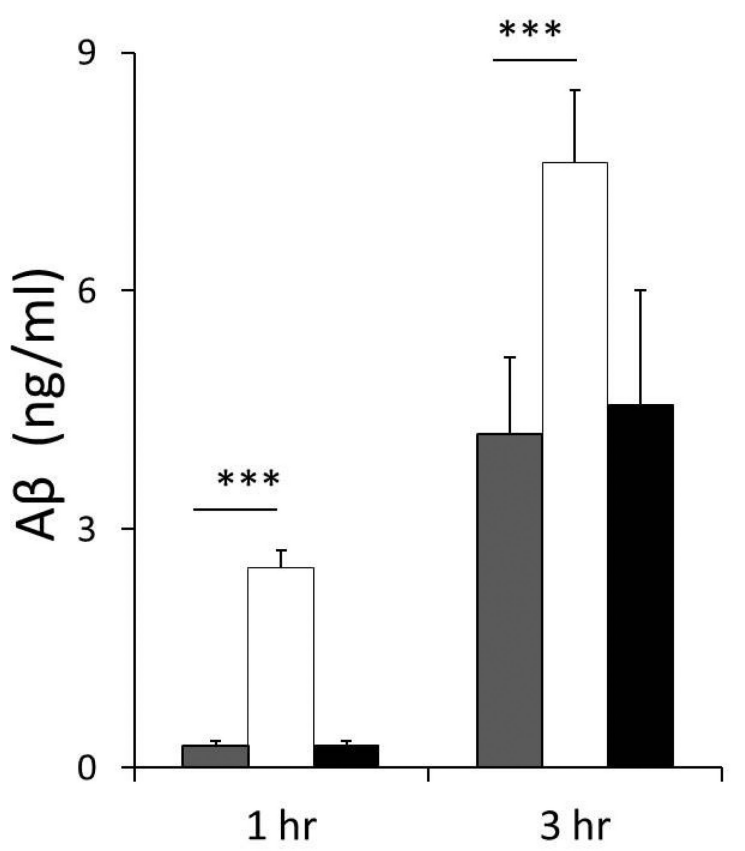

$\square$ Control $\square$ IVIG $\square$ IVIG w/o Anti-A $\beta$

Fig. 4.
B

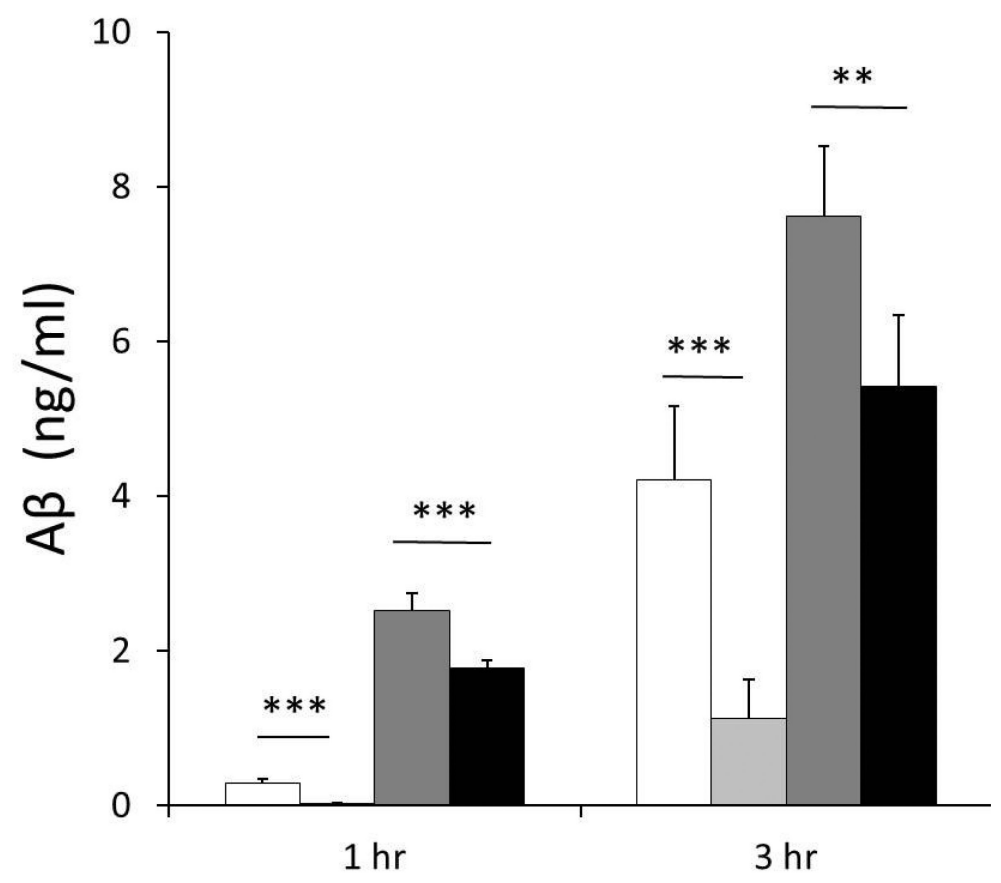

$\square$ Control $\square$ RAP $\square$ IVIG $\quad \square$ IVIG+RAP

Media in outer chambers were added with or without $10 \mathrm{mg} / \mathrm{ml}$ IVIG or IVIG w/o anti-A $\beta$ for 1 to $3 \mathrm{hrs}$ after addition of $1 \mathrm{uM} \mathrm{A} \beta$ into inner chambers. IVIG increases $A \beta$ efflux from inner chambers (A). Treatment of inner chambers with RAP (the LRP1 inhibitor, $100 \mathrm{nM}$ ) significantly inhibited $A \beta$ efflux and IVIG-stimulated $A \beta$ efflux through the formed confluent layer of Z310 cells (B). A $\beta$ in outer chamber media was quantified by ELISA method. Data represent mean \pm SD of three independent experiments, $n=5$. *: $\mathrm{p}<0.05$, **: $p<0.01, * * *: p<0.001$. 

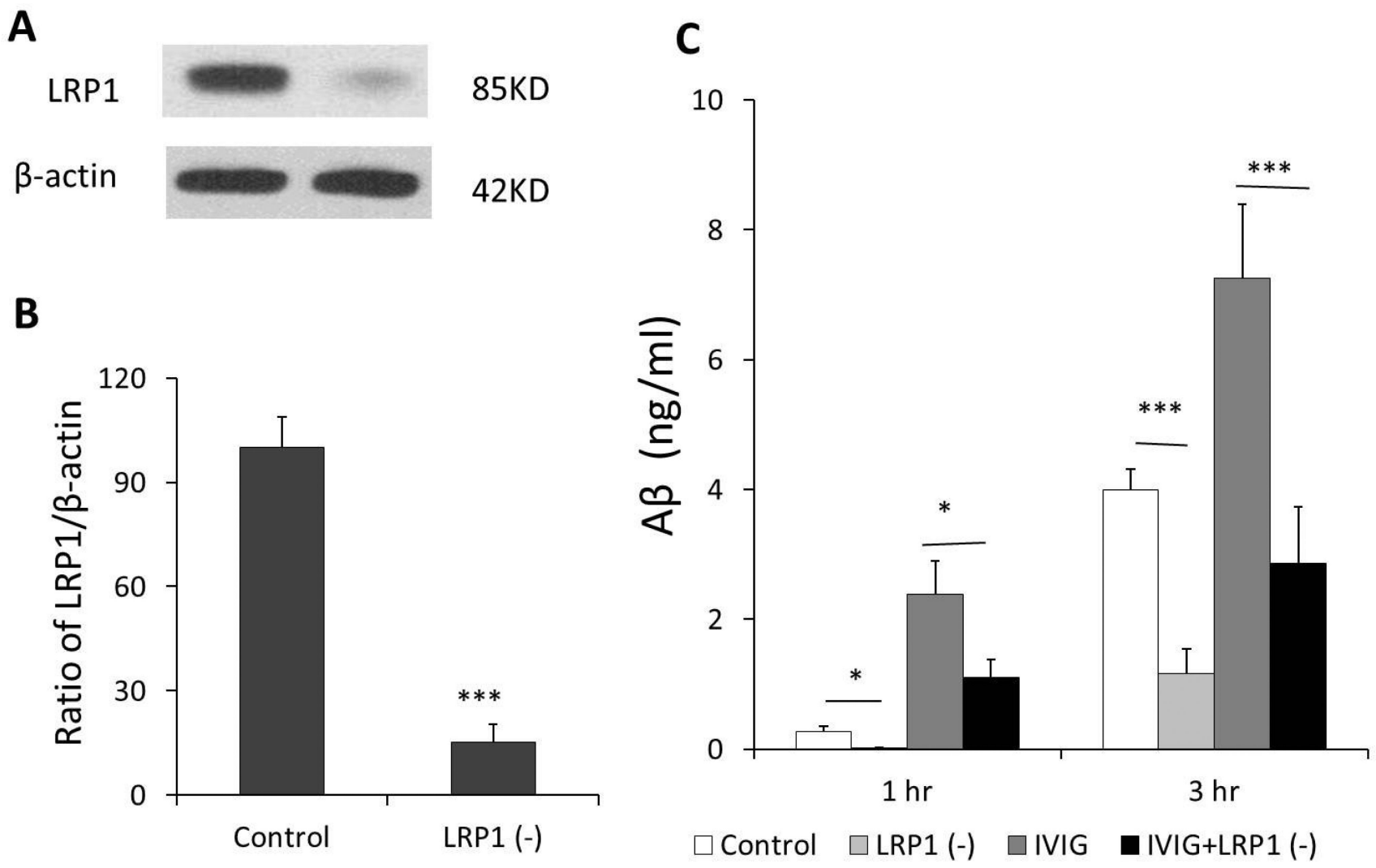

Fig.5.

LRP1 knocked down in Z310 cell by using siRNA. The knockdown efficiency was analyzed by Western blot analysis. Introducing LRP1 siRNA to the cells caused a significant reduction of LRP1 at protein (84.7\%) expression levels as compared to the scrambled siRNA controls (A, B). Media in outer chambers were added with or without $10 \mathrm{mg} / \mathrm{ml}$ IVIG for 1 to $3 \mathrm{hrs}$ after addition of $1 \mathrm{uM} \mathrm{A} \beta$ into inner chambers. LRP1 knockdown by using siRNA decreased $A \beta$ efflux and IVIG-stimulated $A \beta$ efflux through the formed confluent layer of Z310 cells compared with scrambled siRNA controls (C). A $\beta$ in outer chamber media was quantified by ELISA method. Control: scrambled siRNA without IVIG treatment, LRP1 (-): LRP1 knockdown without IVIG treatment, IVIG: scrambled siRNA with IVIG treatment, IVIG+LRP1 (-): LRP1 knockdown cells with IVIG exposure. Data represent mean $\pm \mathrm{SD}$ of three independent experiments, $\mathrm{n}=3 . *$ : $\mathrm{p}<0.05, * * *: p<0.001$. 